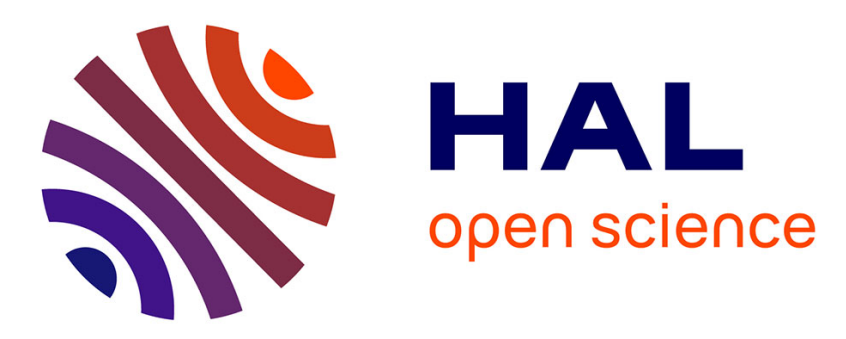

\title{
Effect of Rotor Bar Number on Performance of Five-Phase Induction Machine for Traction
}

\author{
Abdelhak Mekahlia, Eric Semail, Franck Scuiller, Tahar Hamiti, Raouf
}

Benlamine

\section{- To cite this version:}

Abdelhak Mekahlia, Eric Semail, Franck Scuiller, Tahar Hamiti, Raouf Benlamine. Effect of Rotor Bar Number on Performance of Five-Phase Induction Machine for Traction. ICEM, Sep 2018, Alexandropouli, Greece. pp.185-190. hal-01899252

\section{HAL Id: hal-01899252 \\ https://hal.science/hal-01899252}

Submitted on 19 Oct 2018

HAL is a multi-disciplinary open access archive for the deposit and dissemination of scientific research documents, whether they are published or not. The documents may come from teaching and research institutions in France or abroad, or from public or private research centers.
L'archive ouverte pluridisciplinaire HAL, est destinée au dépôt et à la diffusion de documents scientifiques de niveau recherche, publiés ou non, émanant des établissements d'enseignement et de recherche français ou étrangers, des laboratoires publics ou privés. 


\title{
Effect of Rotor Bar Number on Performance of Five-Phase Induction Machine for Traction
}

\author{
Abdelhak Mekahlia, Eric Semail, Franck Scuiller, Tahar Hamiti, Raouf Benlamine
}

\begin{abstract}
The paper investigates the effect of the bar number on the performances of a five-phase squirrel-cage induction machine with fractional-slot tooth concentrated winding. With a same stator, five different rotor bar numbers are chosen and the rotor magnetic circuits are designed using an analytical approach. Then, a finite-element analysis is done under two different supply conditions: fundamental currents and third harmonic currents. Finally regarding the used winding specificities the possibility of second harmonic current supply is evaluated. The results are presented in a comparative way in order to determine the impact of rotor bar number on torque quality for the different supply modes.
\end{abstract}

Index Terms-- Bar number, Constant Power Speed Ratio, Constant Power Speed Range, Five-phase induction machine, Multiphase machine, Torque quality, Traction machine.

\section{NOMENCLATURE}

spp: Number of slots per pole and per phase.

s: Slip.

$\Omega$ : Mechanical speed.

$\Omega_{\mathrm{s}}$ : Synchronism speed.

$\mathrm{f}_{\mathrm{s}}$ : Stator currents frequency.

p: Number of pole-pair.

- $\theta_{\mathrm{e}}$ : Electrical angle

\section{INTRODUCTION}

$\mathrm{E}$ LECTRICAL machines in automotive applications have to satisfy several requirements, especially a wide constant power speed range (CPSR), high torque density, high efficiency and reasonable cost. The idealized torque-speed characteristic required for traction machine is presented in Fig. 1. The constant power region has to be as extended as possible (typically 4 to 5 times the base speed) for medium sized (C segment) electrical vehicle, in order to reach high speed without oversizing the power electronic inverter [1].

Permanent magnet synchronous machines (PMSM) are considered as the best option regarding the aforementioned requirements, especially the CPSR which can reach 5 times the base speed for IPMSM (Interior Permanent Magnets Synchronous Machines) [2]. In addition IPMSM are characterized by their high torque and power density and high efficiency [3]. However, because of the use of

A. Mekahlia and E. Semail are with Univ. Lille, Centrale Lille, Arts et Metiers ParisTech, HEI, HeSam, EA 2697 - L2EP - Laboratoire d'Electrotechnique et d'Electronique de Puissance, F-59000 Lille, France (e-mail: abdelhak.mekahlia@ensam.eu, eric.semail@ensam.eu).

A. Mekahlia, T. Hamiti and R. Benlamine are with Institut Vedecom, F78000 Versailles, France (e-mail: abdelhak.mekahlia@vedecom.fr, tahar.hamiti@vedecom.fr, raouf.benlamine@vedecom.fr).

F. Scuiller is with IRENAV - Research Institute of Naval Academy, BCRM Brest - EN/GEP, F-29240 Brest, France (franck.scuiller@ecolenavale.fr). expensive rare earth materials they have a considerable cost comparing to other machines without permanent magnets[4].

Another type of electrical machines suitable for traction applications is the Switched Reluctance Machines (SRM). These machines have many advantages, especially their very wide CPSR which can reach 7 times the base speed [1] with low cost. However the control strategies for this type of machines are complex due to specific supply currents waveforms. In addition low power factor, harmful acoustic noise, mechanical vibration, torque ripple [5] are also usual.

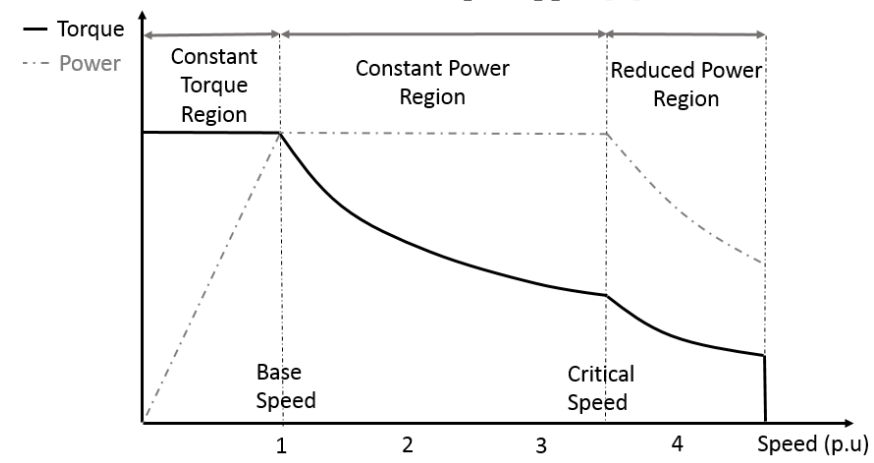

Fig. 1. Idealized Torque-Speed characteristics for traction machine.

Induction machines are becoming more attractive for different vehicle manufacturers thanks to their relatively low cost, in addition to their high robustness and relatively easy manufacture. However these machines are limited regarding CPSR, which is about 2 to 3 times the base speed, and torque density [1], [6].

In order to improve torque density of induction machine the raise of the number of phases can be a good solution. The use of more than three phases allows the injection of adequate current harmonics to improve torque production in the presence of space harmonics, while keeping an acceptable level of torque ripple [7].



Fig. 2 : Theoretical torque-speed characteristic with pole-pairs switching.

In addition, a high number of phases offers the possibility to change the number of pole-pairs in order to extend the CPSR. In fact, the machine can be supplied with high order 
current harmonics in the low speed region of the torquespeed characteristic where torque production can reach its maximum. With decreasing the number of pole-pairs by reducing the supply currents harmonic order, mechanical speed can be increased while constant power operation can be achieved without extended flux weakening, as shown in Fig. $2[8]$.

Keeping in mind the aforementioned potential torque improvement features inherent to the multiphase induction machines, the multiphase machine stator winding must be designed in order to generate different number of pole-pairs. It is not only one winding factor, associated to the fundamental harmonic, which must be of high value as it is classically the case with integral-slot winding. In the paper, the chosen winding (Fig 3) presents significant winding factors for the four first harmonics (one to four) and is also easy to manufacture with short-end winding since it is tooth concentrated [9]. With a slot number per pole and per phase (spp) equal to 0.5 as for numerous machines for automotive, this winding has been used in a synchronous machine which has the ability to develop the same torque either with the first or with the third harmonic current thanks also to a special design of the rotor [10].

For a squirrel cage rotor, an important parameter of design is the number of bars since it impacts average torque, torque harmonics and mechanical vibrations [11]. As consequence, this paper contains a study on the effect of the rotor bar number on the torque (average and quality) of five-phase induction machines under different supply modes: classically first and third current harmonics separately as it is done for Permanent Magnet Synchronous machines and for multiphase induction machines with integral-slot windings [7]. A comparison between five rotors with the same stator is done using transient finite element method under Maxwell (Ansys). Finally, a usual ability of these five-phase machines is also presented: the production of torque with the second harmonic.

\section{MACHINE SPECIFICATIONS}

The five induction machines have the same stator and different rotors.

\section{A. Stator}

The chosen five-phase stator contains 20 slots, with 4 pole-pairs and $\mathrm{spp}=0.5$ with the first harmonic. The stator geometry and winding scheme are illustrated in the Fig. 3.

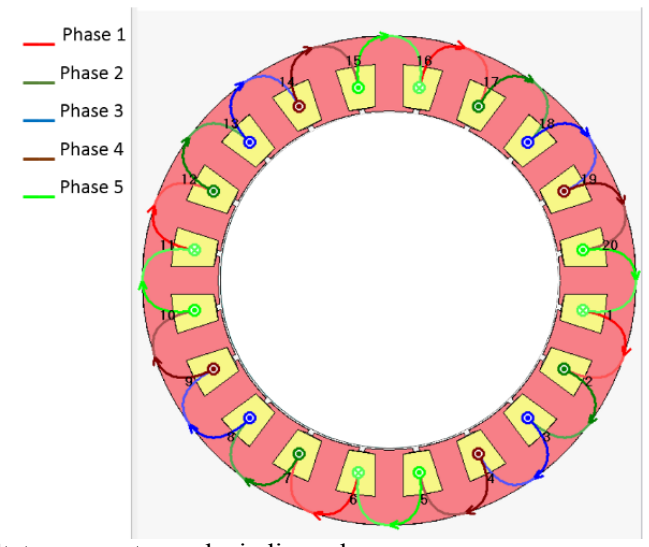

Fig. 3. Stator geometry and winding scheme.
The fractional slot concentrated winding has a factor of $59 \%$ for the first space harmonic and $95 \%$ for the third space harmonic.

The Table I shows the rated parameters and general dimensions of the stator.

TABLE I

MACHINE PARAMETERS

\begin{tabular}{|l|l|l|}
\hline Parameter & Unit & Value \\
\hline Rated power & $\mathrm{kW}$ & 75 \\
\hline $\begin{array}{l}\text { Number of pole-pairs with } \\
\text { the first harmonic }\end{array}$ & 4 \\
\hline $\begin{array}{l}\text { Number of pole-pairs with } \\
\text { the third harmonic }\end{array}$ & 12 \\
\hline Rated frequency & $\mathrm{Hz}$ & 200 \\
\hline Rated speed & $\mathrm{RPM}$ & 3000 \\
\hline DC-bus voltage & $\mathrm{V}$ & 285 \\
\hline Active length & $\mathrm{mm}$ & 150 \\
\hline Airgap thickness & $\mathrm{mm}$ & 0,5 \\
\hline External diameter of stator & $\mathrm{mm}$ & 260 \\
\hline Internal diameter of stator & $\mathrm{mm}$ & 180 \\
\hline
\end{tabular}

\section{B. Rotor}

In order to perform the expected comparison between different rotors with different bar numbers, the considered assumptions concerning the choice of rotor bar number that allows to avoid dangerous synchronous torques, slot harmonics and mechanical vibrations are described in [11]. Five rotor bar numbers were chosen, as shown in Table II, and for each of them the rotor dimensions were calculated basing on the analytical approach described in chapter 15 of [12].

TABLE II

CHOSEN ROTOR BARS NUMBERS

\begin{tabular}{|l|l|l|l|}
\hline Bar number & Parity & Order & Specificity \\
\hline 13 & Odd & Low & Prime \\
\hline 18 & Even & Low & $/$ \\
\hline 35 & Odd & Medium & Multiple of phases number \\
\hline 64 & Even & High & $/$ \\
\hline 65 & Odd & High & Multiple of phases number \\
\hline
\end{tabular}

Fig. 4 illustrates the five machines with different rotors and the same stator. These machines were modeled using Maxwell (Ansys), and the Finite-Element analysis was done under different current supply conditions:

- fundamental only,

- third harmonic only,

- $\quad$ second harmonic only (possible for this winding).

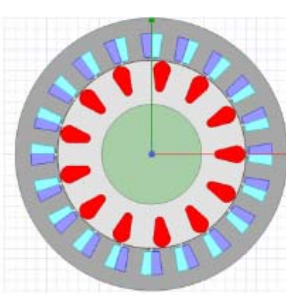

(a) : IM with 13 rotor bars

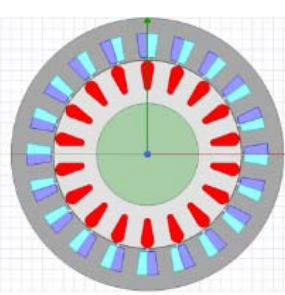

(b) : IM with 18 rotor bars

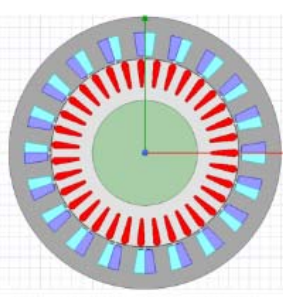

(c) : IM with 35 rotor bars

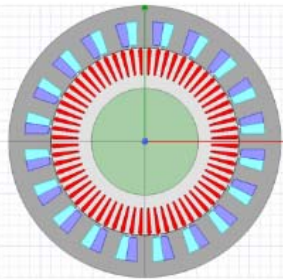

(d) : IM with 64 rotor bars

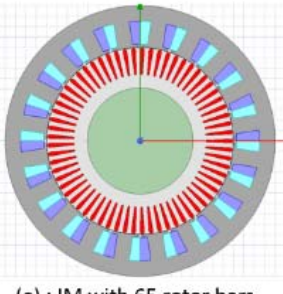

(e) : IM with 65 rotor bars
Fig. 4. The five machines modeled under Maxwell (Ansys). 


\section{COMPARISON UNDER $1^{\text {ST }}$ HARMONIC SUPPLY}

The five machines shown in Fig. 4 were simulated under imposed current supply condition. For the first harmonic supply case the fundamental current was imposed (400 $\mathrm{A}_{\max }$, $50 \mathrm{~Hz})$ with a mechanical speed of " $(1-\mathrm{s}) .750 \mathrm{rpm}$ ", "s" is the slip.

In this supply mode, the number of pole-pair is equal to 4, the synchronous speed is $750 \mathrm{rpm}$.

$$
\Omega_{s}=\frac{60 \cdot f_{s}}{p_{1}}=\frac{60.50}{4}=750 \mathrm{rpm}
$$

\section{A. Torque-Slip curves}

For the five machines, simulations with sweep of slip value between 0 and $4 \%$ are done with a slip step increment of $0.25 \%$. The mean torque was taken for each slip value and the results are shown in the Fig. 5 where one can observe that both the maximum torque and its corresponding slip value increase with the number of bars.

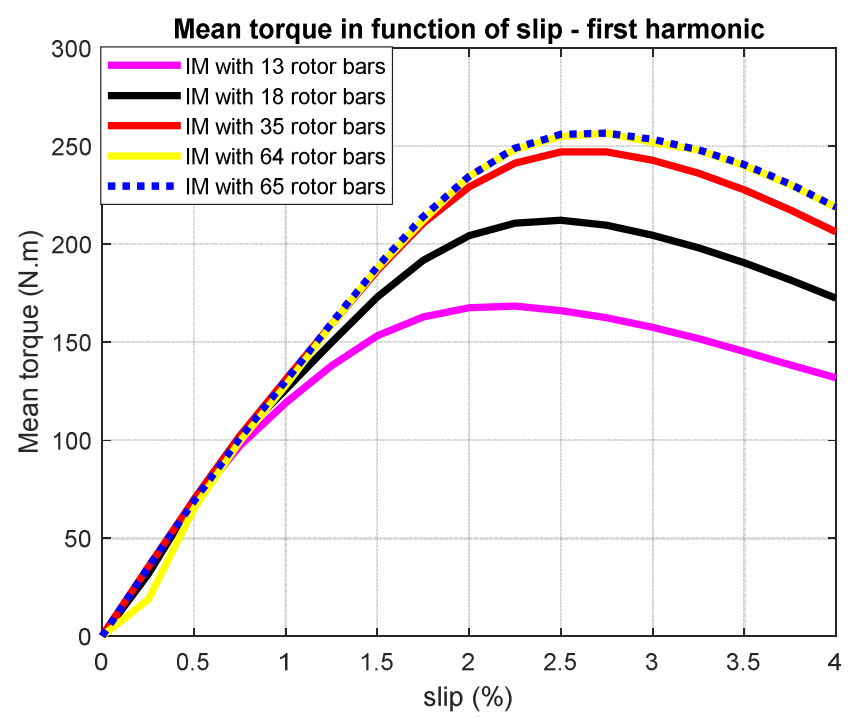

Fig. 5. Mean torque in function of slip $-1^{\text {st }}$ harmonic supply.

A high number of bars appears to be favorable for a higher maximum torque value.

\section{B. Torque quality at maximum value}

From the results shown in the Fig. 5, the slip at maximum torque is determined for the five machines and used in FiniteElement simulations under $1^{\text {st }}$ harmonic supply with a little time step size so as to increase accuracy with regards to the torque pulsations.

The variation of torque at steady-state under optimal slip is illustrated in the Fig. 6 . It can be noted that the quality of torque is strongly impacted by the rotor bar number.

In Table III, the mean value of torque and the corresponding slip for maximum values are given. Torque ripple is obtained after dividing the peak-to-peak value (P2P in Fig. 6) by the mean torque. If the maximum torque increases with the number of bars, it is not the case for the quality of torque. The lowest torque ripple is obtained for the rotors with 35 and 65 bars. With reference to these results, it can be observed that the induction machine with 65 rotor bars is the best regarding both average torque and torque ripple, under fundamental current supply. However, a high slip value induces higher rotor copper losses.

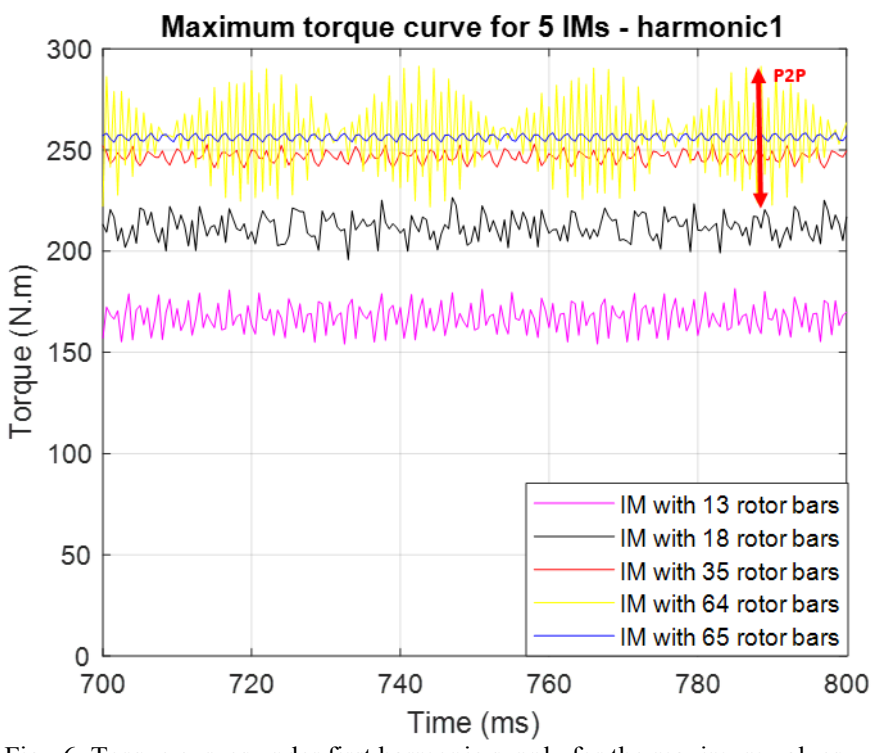

Fig. 6. Torque curves under first harmonic supply for the maximum values.

Consequently, considering steady states operations, the machine with 35 rotor bars could appear as the best compromise between torque quality and efficiency. For payload with transient operations 65 rotor bars could be the best.

TABLE III

MEAN TORQUE AND TORQUE RIPPLE, AT MAXIMUM VALUES UNDER $1^{\text {ST }}$

\begin{tabular}{|c|c|c|c|}
\hline $\begin{array}{l}\text { Bars } \\
\text { number }\end{array}$ & $\begin{array}{l}\text { Slip at } \\
\text { maximum } \\
\text { torque }(\%)\end{array}$ & $\begin{array}{l}\text { Torque } \\
\text { (N.m) }\end{array}$ & $\begin{array}{l}\text { Torque } \\
\text { Ripple } \\
(\%)\end{array}$ \\
\hline 13 & 2.25 & 168 & 16.4 \\
\hline 18 & 2.5 & 212 & 14.5 \\
\hline 35 & 2.5 & 247 & 4.9 \\
\hline 64 & 2.75 & 256 & 27.6 \\
\hline 65 & 2.75 & 256 & 1.8 \\
\hline
\end{tabular}

\section{COMPARISON UNDER $3^{\text {RD }}$ HARMONIC SUPPLY}

One of the advantages of multiphase machines with more than three phases is the possibility of injecting current harmonics to enhance torque production [13]. For the five induction machines of this study the third space harmonic is present in the winding function and its winding factor is $95 \%$. Hence the third harmonic of current can contribute to torque production.

In this part of study, the five induction machines are supplied with currents whose frequency is $150 \mathrm{~Hz}$ and amplitude is $400 \mathrm{~A}$ (the same as for the $1^{\text {st }}$ harmonic supply), and with a mechanical speed of " $(1-\mathrm{s}) .750 \mathrm{rpm}$ ".

In this supply mode, the number of pole pairs is equal to 12 and the synchronous speed is $750 \mathrm{rpm}$.

$$
\Omega_{s}=\frac{60 \cdot f_{s}}{p_{3}}=\frac{60.150}{12}=750 \mathrm{rpm}
$$

The phase sequence under third harmonic supply is different from the fundamental one. As shown in the Fig. 7 the shift between two successive phases is $\theta_{\mathrm{e}}=\frac{2 \pi}{5}$ under the fundamental mode, and $3 . \theta_{\mathrm{e}}$ under the third harmonic mode. 


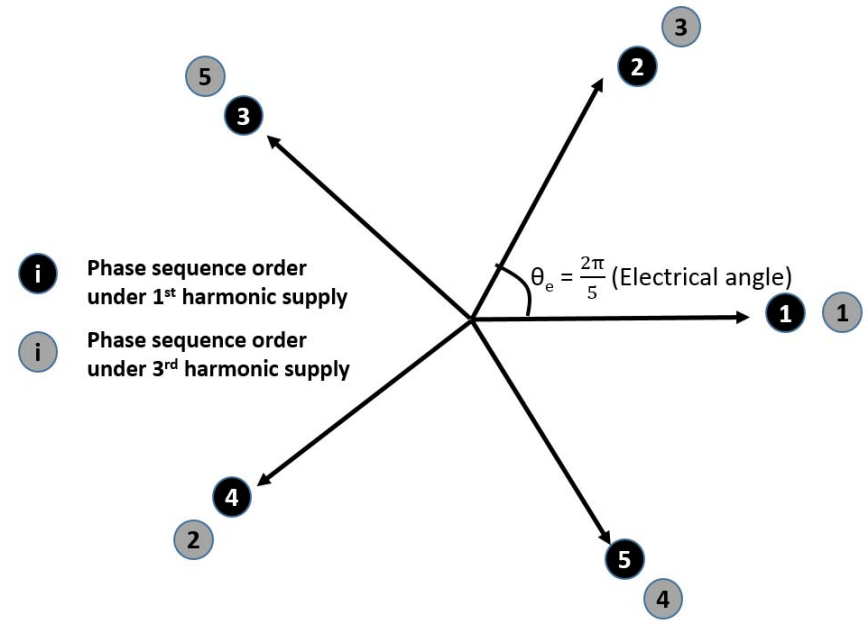

Fig. 7 : Phase sequence under 1st and 3rd harmonic supply.

\section{A. Torque-Slip curves}

As for the first harmonic supply case, the curves of mean torque in function of slip are obtained by the same simulations as for the first harmonic supply, as shown in the Fig. 8. It can be observed that the curves for the machines with 64 and 65 rotor bar are almost identical (in blue and yellow).

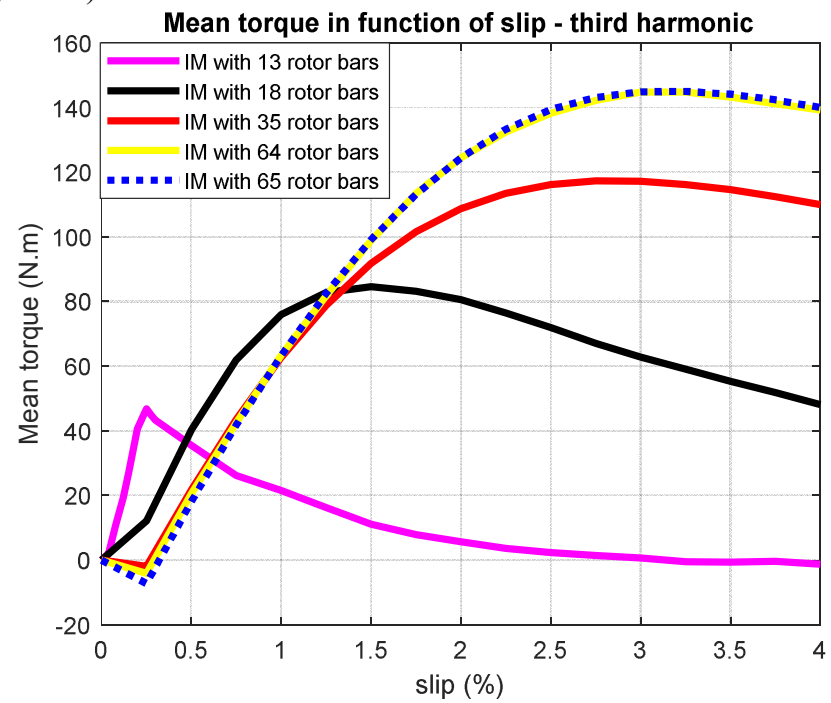

Fig. 8. Mean torque in function of slip $-3^{\text {rd }}$ harmonic supply.

As for the fundamental supply case, it appears that a high number of bars allows to produce higher torque but for higher slips. Besides, the developed torque under this supply mode is lower than with the first harmonic mode even though the third harmonic winding factor is higher than the first harmonic one.

\section{B. Torque quality at maximum values}

From the results shown in the Fig. 8, the slip giving the maximum torque is determined for the five machines, and these values are imposed in Finite-Element simulations under $3^{\text {rd }}$ harmonic supply.

The variation of torque at steady-state under this supply condition at optimal slip is shown in the Fig. 9. It can be observed that the torque quality is also strongly impacted by the number of bars under this supply mode.

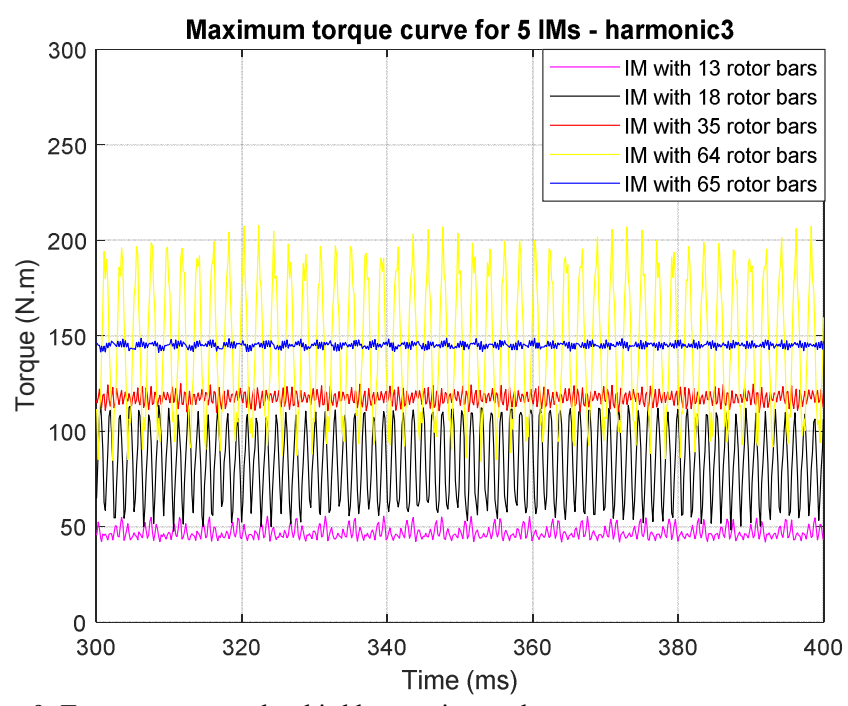

Fig. 9. Torque curves under third harmonic supply.

In Table IV the values of slip, mean torque and torque ripple (calculated by the method described in section IV. B. ) are presented. These results lead to the same observation as for the first harmonic simulations, the level of produced torque increases with the number of bars, and the machine with 65 bars appears to be outperforming regarding torque ripple.

TABLE IV

MEAN TORQUE AND TORQUE RIPPLE, AT MAXIMUM VALUES UNDER THIRD

\begin{tabular}{|l|l|l|l|}
\hline $\begin{array}{l}\text { Bars } \\
\text { number }\end{array}$ & $\begin{array}{l}\text { Slip at } \\
\text { maximum } \\
\text { torque (\%) }\end{array}$ & $\begin{array}{l}\text { Torque } \\
\text { (N.m) }\end{array}$ & $\begin{array}{l}\text { Torque } \\
\text { Ripple } \\
(\%)\end{array}$ \\
\hline 13 & 0.25 & 47 & 30.4 \\
\hline 18 & 1.5 & 84 & 84.0 \\
\hline 35 & 2.75 & 117 & 15.7 \\
\hline 64 & 3.25 & 144 & 85.9 \\
\hline 65 & 3.25 & 144 & 8.1 \\
\hline
\end{tabular}

\section{POSSIBILITY OF USING THE SECOND HARMONIC SUPPLY}

For induction machine, tooth-concentrated windings are not the common solution, probably because they generate odd and even space harmonics. The calculation of the winding factors illustrates this property. According to [14], the Discrete Fourier Transform (DFT) of conductor distribution function inside the slots can be used to estimate the winding factors. For the chosen winding (20 stator slots, 4 pole-pairs and $\mathrm{spp}=0.5$ ) this function is geometrically periodic with a mechanical angle period of $\frac{2 \pi}{p}$.

A sequence of the conductor density function for the 5 phases of the chosen winding is presented in the following matrix (only for one pole-pair):

$D_{1 \text { p-pair }}=\begin{array}{cccccl}\text { Ph 1 } & \text { Ph 2 } & \text { Ph 3 } & \text { Ph4 } & \text { Ph5 } & \\ 0.5 & 0 & 0 & 0 & -0.5 & \text { Slot 1 } \\ -0.5 & 0.5 & 0 & 0 & 0 & \text { Slot 2 } \\ 0 & -0.5 & 0.5 & 0 & 0 & \text { Slot 3 } \\ 0 & 0 & -0.5 & 0.5 & 0 & \text { Slot 4 } \\ 0 & 0 & 0 & -0.5 & 0.5 & \text { Slot } 5\end{array}$

For a given slot, 0.5 value means that half the conductors inside the slot are forward whereas -0.5 values means they are backward. This matrix is repeated four times to obtain the 
complete conductor distribution matrix $D$, then the winding factors for the 4 first space harmonics are obtained by the DFT of $D$ multiplied by the phase number $N$ to stator slot number $Q_{s}$ ratio.

$$
K_{h}=\frac{N}{Q_{s}} \cdot \operatorname{DFT}\{D\}, \quad h=1,2,3,4
$$

Only the 4 first space harmonics are chosen because:

$$
\begin{gathered}
K_{h+k . N}=K_{h}, \text { with } \quad h=1,2,3,4 \\
K_{5+k . N}=K_{5}=0 \quad(h=N)
\end{gathered}
$$

where $k$ is an integer.

So the winding factors in function of space harmonic are presented in Table V. It can be observed that the even space harmonics exist in this winding, especially the second harmonic whose winding factor $\mathrm{K}_{2}$ is equal to $95 \%$ (the same as the third harmonic).

TABLE V

WINDING FACTOR IN FUNCTION OF SPACE HARMONICS.

\begin{tabular}{|c|c|}
\hline Space harmonic & Winding factor $\mathrm{K}_{\mathrm{h}}$ \\
\hline 1 & 0.59 \\
\hline 2 & 0.95 \\
\hline 3 & 0.95 \\
\hline 4 & 0.59 \\
\hline
\end{tabular}

Classically only the first and third harmonic supplies are used for five phase induction machines with classical integral-slot distributed windings. The tooth-concentrated winding under consideration has the particularities of generating even order space harmonics, it should be possible to generate torque by second harmonic currents supply. Similarly to fundamental and third harmonic modes, finiteelement simulations are computed for the five induction machines under second harmonic currents supply, with the same amplitude of $400 \mathrm{~A}$. The torque variation for the five machines is illustrated in Fig. 10 and the values of mean torque and torque ripple are presented in Table VI.

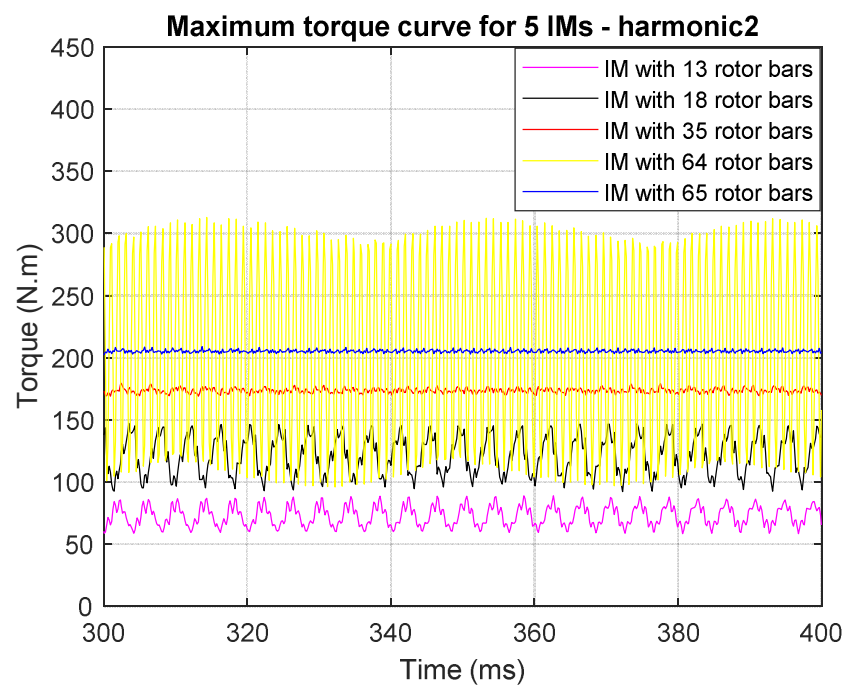

Fig. 10. Torque curves under second harmonic supply.

The same conclusion as for the fundamental and third harmonic modes can be drawn: the increase of bar number is favorable for the torque production, the worst bar number regarding torque ripple is 64 , and the machines with 35 and 65 rotor bars have a low torque ripple.
TABLE VI

MEAN TORQUE AND TORQUE RIPPLE, AT MAXIMUM VALUES UNDER SECOND HARMONIC SUPPLY.

\begin{tabular}{|l|l|l|l|}
\hline $\begin{array}{l}\text { Bars } \\
\text { number }\end{array}$ & $\begin{array}{l}\text { Slip at } \\
\text { maximum } \\
\text { torque (\%) }\end{array}$ & $\begin{array}{l}\text { Torque } \\
(\mathrm{N} . \mathrm{m})\end{array}$ & $\begin{array}{l}\text { Torque } \\
\text { Ripple } \\
(\%)\end{array}$ \\
\hline 13 & 1.25 & 73 & 44 \\
\hline 18 & 2.5 & 122 & 51 \\
\hline 35 & 2.65 & 173 & 7.9 \\
\hline 64 & 3 & 205 & 107 \\
\hline 65 & 3 & 205 & 3.4 \\
\hline
\end{tabular}

Similarly to the third harmonic supply mode, the developed torque under the second harmonic is lower than the fundamental mode torque although the winding factor for this harmonic is $95 \%$.

The ratio of developed torque under $2^{\text {nd }}$ and $3^{\text {rd }}$ harmonic to the fundamental mode torque is calculated and presented in Table VII for the five machines.

TABLE VII

TORQUE REDUCTION ORDER UNDER $2^{\text {ND }}$ AND $3^{\text {RD }}$ HARMONIC MODES.

\begin{tabular}{|c|c|c|}
\hline $\begin{array}{c}\text { Bars } \\
\text { number }\end{array}$ & $\begin{array}{c}\text { Torque } 2^{\text {nd }} \text { harmonic } \\
/ \text { Torque } 1^{\text {st }} \text { harmonic } \\
(\%)\end{array}$ & $\begin{array}{c}\text { Torque } 3^{\text {rd }} \text { harmonic } \\
/ \text { Torque } 1^{\text {st }} \text { harmonic } \\
(\%)\end{array}$ \\
\hline 13 & $43 \%$ & $28 \%$ \\
\hline 18 & $58 \%$ & $40 \%$ \\
\hline 35 & $70 \%$ & $47 \%$ \\
\hline 64 & $80 \%$ & $56 \%$ \\
\hline 65 & $80 \%$ & $56 \%$ \\
\hline
\end{tabular}

It can be observed that a high number of rotor bars appears to be favorable for the use of the second and third harmonic supplies since the resulting torques (relative to the 1 st harmonic torque) are increased.

\section{CONCLUSION}

In comparison with PM machines, the filtering effect of an induction rotor under the excitation of different harmonics of stator currents is more complex. Using Finite-Element method, the paper has investigated the impact of the rotor bar number on the developed torque in five-phase induction machine under first and third harmonic supplies but also for a second harmonic. Five rotor bar numbers (13 to 65) have been chosen according to the design procedure described in [11]. It is appearing that the maxima capabilities in terms of maximum average torque are obtained with a high number of bars. On contrary, the quality of torque is good with 65 bars which is a $13 \times 5$ but is poor with 64 bars.

It has been shown also that the cage rotor reacts significantly to the rotating field generated by an even second harmonic of current. As the generated torque is quite significant, it is meaning that when even harmonics are existing in the winding function the control must also consider even harmonics of currents and not only as usual odd, first and third harmonics.

Generally, if the rotor is simpler with induction machine in comparison with Permanent Magnet machines, the constraints on the winding appear as more important for induction machines.

Further work is ongoing regarding harmonics interactions and energy conversion mechanisms in multiphase induction machines. 


\section{REFERENCES}

[1] Z. Q. Zhu and D. Howe, "Electrical Machines and Drives for Electric, Hybrid, and Fuel Cell Vehicles," Proc. IEEE, vol. 95, no. 4, pp. 746-765, 2007.

[2] J. M. Mun, G. J. Park, S. H. Seo, D. W. Kim, Y. J. Kim, and S. Y. Jung, "Design Characteristics of IPMSM with Wide Constan

Power Speed Range for EV Traction," IEEE Trans. Magn., vol. 53, no. 6, pp. 6-9, 2017.

[3] W. Xu, J. Zhu, Y. Guo, S. Wang, Y. Wang, and Z. Shi, "Survey on electrical machines in electrical vehicles," 2009 Int. Conf. Appl. Supercond. Electromagn. Devices, ASEMD 2009, no. c, pp. 167$170,2009$.

[4] G. Dajaku and D. Gerling, "Different novel electric machine designs for automotive applications," World Electr. Veh. J., vol. 6, no. 3, pp. 712-718, 2013.

[5] T. J. E. Miller, Switched Reluctance Motors and Their Control. 1993.

[6] A. Fuhs, Hybrid Vehicles and the Future of Personal Transportation. 2008.

[7] A. S. Abdelkhalik, M. Masoud, and W. Barry, "Eleven-phase induction machine: steady-state analysis and performance evaluation with harmonic injection," Electr. Power Appl. IET, vol. 4, no. August 2009, pp. 670-685, 2010.

[8] G. Dajaku, F. Bachheibl, A. Patzak, and D. Gerling, "Intelligent Stator Cage Winding for Automotive Traction Electric Machines," EVS28 Int. Electr. Veh. Symp. Exhib., pp. 1-8, 2015.

[9] O. Moros and D. Gerling, "New flexible harmonic cost effective concentrated winding topology," IECON 2015 - 41st Annu. Conf. IEEE Ind. Electron. Soc., pp. 427-432, 2015.

[10] H. Zahr, J. Gong, E. Semail, and F. Scuiller, "Comparison of optimized control strategies of a high-speed traction machine with five phases and bi-harmonic electromotive force," Energies, vol. 9, no. 12, pp. 1-19, 2016.

[11] J. Pyrhönen, T. Jokinen, and V. Hrabovcovà, Design of rotating electrical machines. 2008.

[12] I. S. a. N. Boldea, Induction Machine. 2012.

[13] A. S. Abdel-Khalik, M. I. Masoud, S. Ahmed, and A. M. Massoud, "Effect of current harmonic injection on constant rotor volume multiphase induction machine stators: A comparative study," IEEE Trans. Ind. Appl., vol. 48, no. 6, pp. 2002-2013, 2012 .

[14] F. Scuiller, E. Semail, and J.-F. Charpentier, "General modeling of the windings for multi-phase ac machines," Eur. Phys. J. Appl. Phys., vol. 50, no. 3, p. 31102, 2010.

\section{BIOGRAPHIES}

Abdelhak Mekahlia was born in Annaba, Algeria, on April 19, 1991. He obtained his engineer degree from the ENP "Ecole Nationale Polytechnique", Algiers, and a Master degree from ParisTech, France. His employment experience included Akka Technologies Company and Vedecom institute in France. His special fields of interest included electrical machines and control strategies.
Actually he is preparing his Ph.D degree at ENSAM School "Arts et Metiers ParisTech", L2EP Laboratory "Laboratoire d'Electrotechnique et d'Electronique de Puissance" and Vedecom institute, France.

Eric Semail graduated in 1986 from the Ecole Normale Supérieure, in France. He received Ph.D. degree in 2000 on " Tools and studying method of polyphase electrical systems, Generalization of the space vector theory ». He became Associate Professor at Engineering school of ARTS et METIERS ParisTech in 2001 and full Professor in 2010.

In Laboratory of Electrical Engineering of Lille (L2EP) in France, his fields of interest include design, modeling and control of multi-phase electrical drives (converters and AC Drives). More generally, he studies, as member of the Control team of L2EP, Multi-machine and Multi-converter systems. Fault Tolerance for electromechanical conversion at variable speed is one of the applications of the research with industrial partners in fields such as automotive, marine and aerospace. Since 2002, he has collaborated to the publication of 30 scientific journals, 71 International Congresses, 5 patents and 2 chapters in books at Wiley editions.

Franck Scuiller received the Electrical Engineering degree (M.Sc. degree) from ENSIEG, INPG (Grenoble National Polytechnic Institute) in 2001 and the Ph.D. Degree from "Arts et Métiers ParisTech" in 2006. In 2007, he was a lecturer in French Naval Academy. From 2008 to 2011, he was a technical project manager in warship electric power systems for DCNS Company (Lorient, France). Since September 2011, he is an Associate Professor in Electrical Engineering in the French Naval Academy. His research interest is multi-phase machines for marine applications (ship propulsion, marine current turbine).

Tahar Hamiti was born in Larbàa Nath Irathen, Algeria, in 1979. He received the Ingénieur d'Etat degree in automatic control systems from the University of Tizi-Ouzou, Tizi-Ouzou, Algeria, and the Ph.D. degree in electrical engineering from the University of Lorraine, Nancy, France.

From 2010 to 2015, he was a Research Fellow and subsequently a Lecturer within the Power Electronics, Machines and Control Group, The University of Nottingham, UK.

In 2015 Dr Hamiti joined VEDECOM, a French institute for energy transition to work on novel electrical machines for electric and hybrid vehicles. His research interests include modeling, optimal design, and control of high-performance electrical machines for transportation applications and power generation.

Raouf Benlamine was born in Algiers, Algeria, in 1987. He received the Engineering degree in electrical engineering from Ecole Nationale Polytechnique, Algiers, in 2010, and the Master degree in electrification and automotive propulsion from the Ecole Centrale de Paris, France, in 2011. In 2014, he received his $\mathrm{Ph} . \mathrm{D}$. degree from the University of Franche-Comte (France) in collaboration with Renault. His doctoral research dealt with the design and the optimization of axial-flux PM machines for hybrid electric vehicle application.

Since 2015, Dr Benlamine works as electrical machines design engineer at VEDECOM Institute. His current research interests include the modeling and the design of high-performance electrical machines (axial and radial-flux) for transportation applications. 